\title{
Biological Thiols and Carbon Disulfide: The Formation and Decay of Trithiocarbonates under Physiologically Relevant Conditions
}

\author{
Maykon Lima Souza, ${ }^{\dagger, \S}$ Anthony W. DeMartino, ${ }^{\dagger,+}$ and Peter C. Ford*(i) \\ Department of Chemistry and Biochemistry, University of California at Santa Barbara, Santa Barbara, California 93106-9510, United \\ States
}

Supporting Information

ABSTRACT: Carbon disulfide is an environmental toxin, but there are suggestions in the literature that it may also have regulatory and/or therapeutic roles in mammalian physiology. Thiols or thiolates would be likely biological targets for an electrophile, such as $\mathrm{CS}_{2}$, and in this context, the present study examines the dynamics of $\mathrm{CS}_{2}$ reactions with various thiols (RSH) in physiologically relevant near-neutral aqueous media to form the respective trithiocarbonate anions $\left(\mathrm{TTC}^{-}\right.$, also known as "thioxanthate anions"). The rates of $\mathrm{TTC}^{-}$formation are markedly $\mathrm{pH}$-dependent, indicating that the reactive form of $\mathrm{RSH}$ is the conjugate base $\mathrm{RS}^{-}$. The rates of the reverse reaction, that is, decay of $\mathrm{TTC}^{-}$anions to release $\mathrm{CS}_{2}$, is $\mathrm{pH}$-independent, with rates roughly antiparallel to the basicities of the $\mathrm{RS}^{-}$conjugate base. These observations indicate that the rate-limiting step of decay is simple $\mathrm{CS}_{2}$ dissociation from $\mathrm{RS}^{-}$, and according to microscopic reversibility, the transition state of $\mathrm{TTC}^{-}$formation would be simple addition of the $\mathrm{RS}^{-}$nucleophile to the $\mathrm{CS}_{2}$ electrophile. At $\mathrm{pH} 7.4$ and $37^{\circ} \mathrm{C}$, cysteine and glutathione react with $\mathrm{CS}_{2}$ at a similar rate but the trithiocarbonate product undergoes a slow cyclization to give 2-thiothiazolidine-4-carboxylic acid. The potential biological relevance of these observations is briefly discussed.

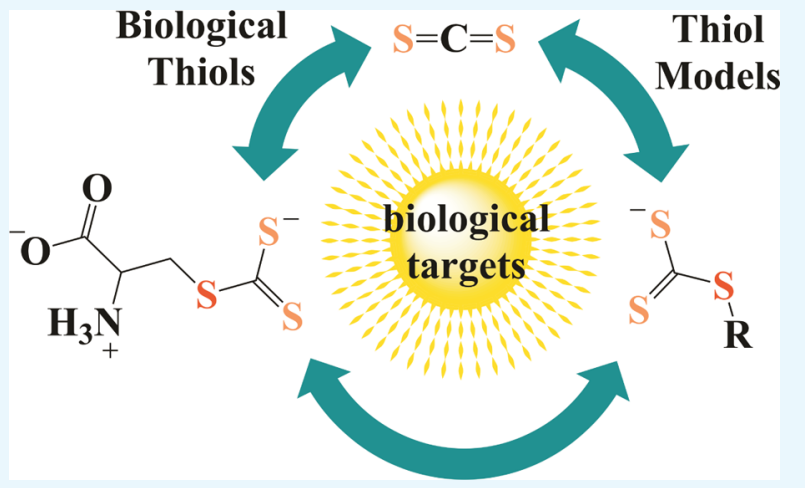

\section{INTRODUCTION}

This laboratory has recently compiled literature information on the known and suggested physiological properties of carbon disulfide $\left(\mathrm{CS}_{2}\right)$ and identified certain analogies to the smallmolecule bioregulators (SMBs) nitric oxide, carbon monoxide, and hydrogen sulfide (sometimes called "gasotransmitters"). ${ }^{1}$ The common properties of these SMBs include partial solubility in aqueous and lipid systems, the ability to diffuse readily in physiological structures, and known toxicity at higher concentrations. ${ }^{2}$ Similarly, $\mathrm{CS}_{2}$ is a nonpolar, readily diffusible molecule considered to be an environmental toxin. ${ }^{3}$ In addition, there are indications that $\mathrm{CS}_{2}$ is formed endogenously or in the associated gut microbiome of mammals. ${ }^{4}$ Biological sulfhydryls ( $\mathrm{R}-\mathrm{SH}$ ) would be likely targets, and the dynamics of the "on" and "off" reactions of this electrophile with such nucleophiles should be crucial to any physiological roles. Thus, the present study is focused on exploring the reactivity of $\mathrm{CS}_{2}$ with thiols, such as cysteine ( $\mathrm{CysSH}$ ) and glutathione (GSH), as well as with several model thiols to form trithiocarbonate anions ( $\mathrm{TTC}^{-}$, also known as "thioxanthate anions") in near-neutral aqueous media (eq 1). From the biomedical perspective, the trithiocarbonate anion $\left(\mathrm{PhCH}_{2} \mathrm{SCS}_{2}^{-}\right)$has been studied as an inhibitor to carbonic anhydrases and as a possible therapeutic in glaucoma treatment. ${ }^{5}$ However, to our knowledge, the dynamics of the formation and decay of TTC salts under physiologically relevant conditions have not been previously reported.

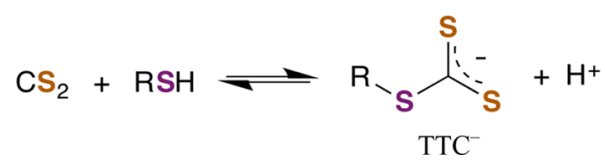

Elucidating prospective biological roles of carbon disulfide will depend on having vehicles for controlled $\mathrm{CS}_{2}$ release under experimental biological conditions. Certain TTCs are unstable toward the slow release of carbon disulfide, ${ }^{6}$ and such reactivity may be relevant to the biological activity of $\mathrm{CS}_{2}$ as well as a desirable property for $\mathrm{CS}_{2}$ delivery. In this context, we describe the kinetics of $\mathrm{CS}_{2}$ dissociation from several prepared $\mathrm{TTC}^{-}$ salts in aqueous solution. The latter studies complement earlier investigations of $\mathrm{CS}_{2}$ generation by photosensitized oxidation of 1,1-dithiooxalate ${ }^{7}$ and by the thermal decay of dithiocarbamate anions. ${ }^{8}$ The $\mathrm{CS}_{2}$ release rates from the latter precursors vary considerably, thereby providing a wide range of activities for physiological experiments. The TTC derivatives of $\mathrm{CysSH}$ and GSH also undergo a slow cyclization reaction to give 2thiothiazolidine-4-carboxylic acid (TTCA), a product that, when found in the urine, is considered diagnostic of exposure

Received: August 18, 2017

Accepted: September 26, 2017

Published: October 9, 2017 
to carbon disulfide. ${ }^{9,10}$ Notably, this cyclization also releases an equivalent of hydrogen sulfide.

\section{RESULTS AND DISCUSSION}

Trithiocarbonate Decay. As noted above, we have recently described the kinetics for a set of dithiocarbamate salts that decay by releasing $\mathrm{CS}_{2}$ with lifetimes ranging from seconds to days in near-neutral, aerobic aqueous media at 37 ${ }^{\circ} \mathrm{C}$. ${ }^{8}$ In this section, we describe analogous decays of several $\mathrm{RSCS}_{2}{ }^{-}$anions under similar conditions.

The $\mathrm{TTC}^{-}$salts used here were prepared by the reaction of the corresponding thiol precursor with $\mathrm{CS}_{2}$ in strongly alkaline solution. The electronic spectrum of each displays intense absorption bands at approximately 310 and 330-350 nm with extinction coefficient of $\sim 8 \times 10^{3} \mathrm{M}^{-1} \mathrm{~s}^{-1}$ (e.g., Figure 1) that

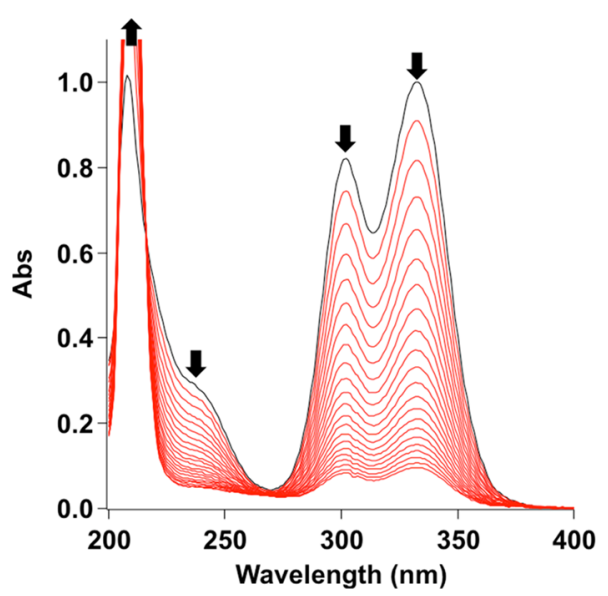

Figure 1. Temporal solution spectra at $49 \mathrm{~s}$ intervals tracking the decay of $\mathrm{Na}_{2}$ [PTTC] (initially about $0.11 \mathrm{mM}$ ) in $\mathrm{pH} 7.4,37{ }^{\circ} \mathrm{C}$ aqueous solution (phosphate buffer at $100 \mathrm{mM}$ ). The increasing absorbance at $206 \mathrm{~nm}$ is consistent with the strong absorbance of $\mathrm{CS}_{2}$ at this wavelength.

we assign to $\pi \rightarrow \pi^{*}$ transitions largely localized on the $-\mathrm{SCS}_{2}{ }^{-}$ functional group. Time-dependent density functional theory calculations (Supporting Information (SI) Figure S1) support this assignment. Similar but somewhat higher-energy absorptions are seen in the spectra of analogous dithiocarbamate $\left(\mathrm{R}_{2} \mathrm{NCS}_{2}^{-}\right)$and xanthate $\left(\mathrm{ROCS}_{2}^{-}\right)$anions. ${ }^{8,11}$

Decays of the TTC anions in aqueous media are readily followed by the temporal decreases of these two UV bands (Figure 1). These spectral changes were accompanied by the release of at least $90 \%$ of the $\mathrm{CS}_{2}$ predicted, for example, by the stoichiometry of eq 2, using the $\mathrm{CS}_{2}$ analysis method described in detail elsewhere ${ }^{7,8}$ and briefly in the Experimental Section.

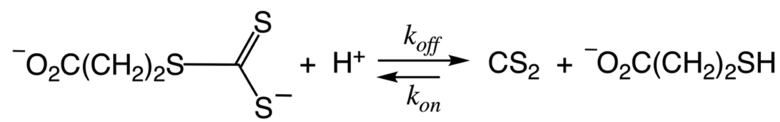

\section{PTTC $^{-}$}

As discussed below, the decays of these $\mathrm{TTC}^{-}$anions are reversible; therefore, it is necessary to take the back-reaction into account as indicated in eq 3 when evaluating the kinetics of the temporal spectral changes. These reactions were conducted in buffered solutions at specific $\mathrm{pH}$ values, and the effects of $\mathrm{pH}$, buffer, and other factors are incorporated into the apparent rate constants $k_{\text {off }}$ and $k_{\text {on }}$ for the forward reaction and backreaction. Although $\left[\mathrm{CS}_{2}\right]$ is not constant during an individual experiment, the temporal spectral data can be fit numerically using a nonlinear least-squares regression program (see Experimental Section and SI Figure S2); however, the $k_{\text {on }}$ values so obtained are inherently less accurate than are the corresponding $k_{\text {off }}$ values.

$$
\mathrm{d}\left[\mathrm{TTC}^{-}\right] / \mathrm{d} t=k_{\text {off }}\left[\mathrm{TTC}^{-}\right]-k_{\text {on }}\left[\mathrm{CS}_{2}\right][\mathrm{RSH}]
$$

Figure 1 illustrates temporal spectral changes observed when a sample of the sodium salt of 3-trithiocarbonatopropionate $\left(\mathrm{Na}_{2}\right.$ [PTTC] $)$ undergoes decay in $\mathrm{pH} 7.4$ aqueous solution at $37{ }^{\circ} \mathrm{C}$ (eq 2). Table 1 summarizes the rate constants $k_{\text {off }}$ and $k_{\text {on }}$

Table 1. $k_{\text {off }}$ and $k_{\text {on }}$ Values Determined for the Decay of PTTC $^{-}$in Aqueous Phosphate Buffer Solution at $37^{\circ} \mathrm{C}$

$\begin{array}{lcc}\mathrm{pH} & k_{\text {off }}\left(\text { in } 10^{-3} \mathrm{~s}^{-1}\right) & k_{\text {on }}\left(\mathrm{M}^{-1} \mathrm{~s}^{-1}\right) \\ 6.5^{a} & 2.43 \pm 0.13 & 0.06 \pm 0.03 \\ 7.4^{b} & 2.36 \pm 0.05 & 0.08 \pm 0.04 \\ 7.8 & 2.36 \pm 0.02 & 0.22 \pm 0.01\end{array}$

${ }^{a} 50 \mathrm{mM}$ phosphate buffer and $\mu=0.154 \mathrm{M} .{ }^{b}$ Average of values determined at 50 and $100 \mathrm{mM}$ phosphate and $\mu=0.154$ and $0.308 \mathrm{M}$.

calculated as described. There was no significant effect of $\mathrm{pH}$ on $k_{\text {off }}$ over the range 6.5-7.8; thus, the decay of $\mathrm{PTTC}^{-}$is not catalyzed by acid, an observation that is in direct contrast to the decay under analogous conditions of the dithiocarbamate ions. The $k_{\text {on }}$ values for the reverse reaction appear to increase with $\mathrm{pH}$, as would be expected, if this step involves the reaction of the electrophile $\mathrm{CS}_{2}$ with the thiolate group of the product. This type of reactivity is discussed in greater detail below. No significant effects were seen for increasing ionic strength from 0.154 to $0.308 \mathrm{M}$ or buffer concentration from 50 to $100 \mathrm{mM}$.

A linear Eyring plot of the $k_{\text {off }}$ values determined for the decay of $\mathrm{PTTC}^{-}$in $\mathrm{pH} 7.4$ aqueous buffer solution over the temperature range of $5-55{ }^{\circ} \mathrm{C}$ (SI Figure S3) gave the activation parameter values $\Delta H^{\ddagger}=70.3 \pm 0.7 \mathrm{~kJ} \mathrm{~mol}^{-1}$ and $\Delta S^{\ddagger}$ $=-69 \pm 2 \mathrm{~J} \mathrm{~K}^{-1} \mathrm{~mol}^{-1}$.

MPTTC $^{-}$, the methyl ester of PTTC $^{-}$, shows similar behavior (eq 4, SI Figure S4). At $37{ }^{\circ} \mathrm{C}$, the rate constant for decay was $(2.40 \pm 0.01) \times 10^{-3} \mathrm{~s}^{-1}$. Kinetics data collected at $27.1,37.0$, and $46.4{ }^{\circ} \mathrm{C}$ at $\mathrm{pH} 7.4$ gave the activation parameters $\Delta H^{\ddagger}=75.7 \pm 0.1 \mathrm{~kJ} \mathrm{~mol}^{-1}$ and $\Delta S^{\ddagger}=-51.4 \pm 0.4 \mathrm{~J} \mathrm{~K}^{-1}$ $\mathrm{mol}^{-1}$.

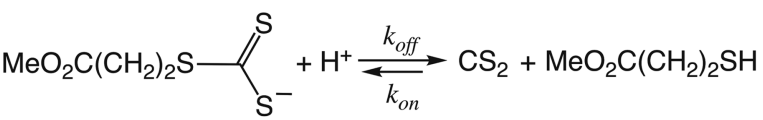

MPTTC $^{-}$

$N$-Acetylcysteine trithiocarbonato anion (NacTTC ${ }^{-}$, eq 5) behaved similarly but gave larger values for both $k_{\text {off }}(0.0118 \pm$ $\left.0.004 \mathrm{~s}^{-1}\right)$ and $k_{\mathrm{on}}\left(0.7 \pm 0.2 \mathrm{M}^{-1} \mathrm{~s}^{-1}\right)$ in $\mathrm{pH} 7.4$ aqueous phosphate buffer solution $(100 \mathrm{mM})$ at $37{ }^{\circ} \mathrm{C}$. An Eyring plot of $k_{\text {off }}$ values measured over the temperature range of $5-55{ }^{\circ} \mathrm{C}$ (SI Figure S3) gave the activation parameter values $\Delta H^{+}=66.8$ $\pm 0.9 \mathrm{~kJ} \mathrm{~mol}^{-1}$ and $\Delta S^{\ddagger}=-67 \pm 3 \mathrm{~J} \mathrm{~K}^{-1} \mathrm{~mol}^{-1}$ quite similar to those determined for the decay of $\mathrm{PTTC}^{-}$. 


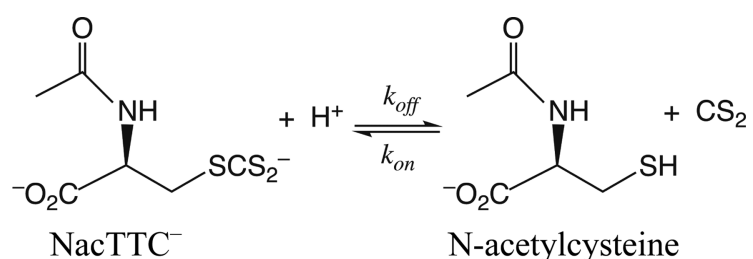

Analogous kinetics studies for decay of the benzyl trithiocarbonate anion (BnTTC ${ }^{-}$, eq 6) displayed decreases in the 302 and $332 \mathrm{~nm}$ absorption band characteristic of such $\mathrm{TTC}^{-}$anions (SI Figure S5). The reactions are somewhat faster than seen for PTTC ${ }^{-}$, but again the rate constants $k_{\text {off }}$ for the forward reaction showed essentially no sensitivity to the solution $\mathrm{pH}$ over the range of 6.5-10.1 (Table 2). In contrast,

Table 2. $k_{\text {off }}$ and $k_{\text {on }}$ Values Determined for the Decay of BnTTC $^{-}$in Aqueous Phosphate Buffer Solution at $37^{\circ} \mathrm{C}$

\begin{tabular}{ccl}
$\mathrm{pH}^{a}$ & $k_{\text {off }}\left(\right.$ in $\left.10^{-3} \mathrm{~s}^{-1}\right)$ & $k_{\text {on }}\left(\mathrm{M}^{-1} \mathrm{~s}^{-1}\right)$ \\
6.5 & $8.8 \pm 0.1$ & \\
7.4 & $8.5 \pm 0.1$ & $0.7 \pm 0.1$ \\
7.8 & $8.5 \pm 0.1$ & $1.8 \pm 0.1$ \\
10.1 & $7.3 \pm 0.1$ & $58 \pm 1$ \\
${ }^{a} 100 \mathrm{mM}$ phosphate buffer and $\mu=0.18-0.29 \mathrm{M}$. & \\
\hline
\end{tabular}

the $k_{\text {on }}$ value calculated was markedly larger at the highest $\mathrm{pH}$, and this was reflected by the reaction not going to completion but reaching an equilibrium or steady state (Figure 2 ).

$\mathrm{PhCH}_{2} \mathrm{~S}-\mathrm{S}_{\mathrm{S}^{-}}^{\mathrm{S}}+\mathrm{H}^{+} \underset{k_{o n}}{\stackrel{k_{\text {off }}}{\rightleftarrows}} \mathrm{CS}_{2}+\mathrm{PhCH}_{2} \mathrm{SH}$

BnTCC

$\mathrm{BnSH}$

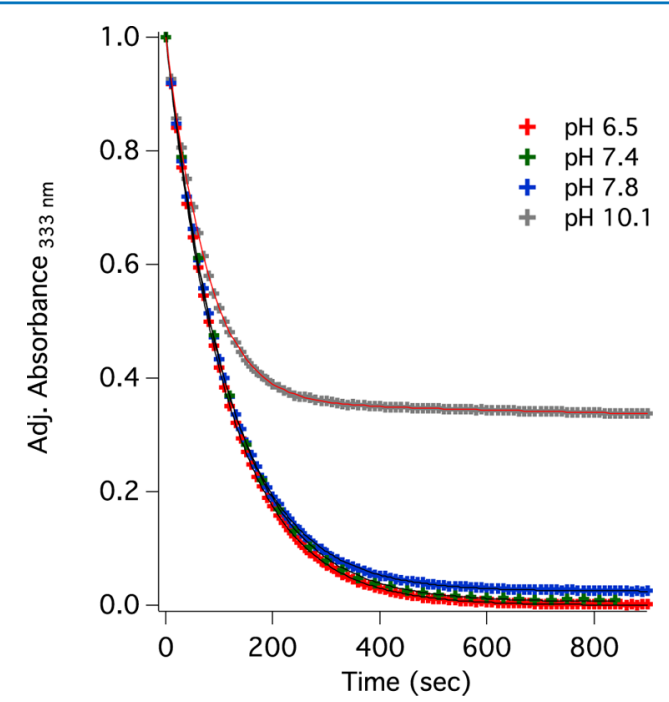

Figure 2. Effect of $\mathrm{pH}$ on the decay kinetics of $\mathrm{BnTTC}^{-}$at $37^{\circ} \mathrm{C}$ and in $0.1 \mathrm{M}$ phosphate buffer, except for $\mathrm{pH} 10.1$, which is in $0.1 \mathrm{M}$ carbonate buffer (all experiments done in duplicate).

The absence of a $\mathrm{pH}$ effect on the $k_{\text {off }}$ values in $37{ }^{\circ} \mathrm{C}$ aqueous media for the decays of $\mathrm{PTTC}^{-}$and $\mathrm{BnTTC}^{-}$is consistent with the rate-limiting step dissociation of $\mathrm{CS}_{2}$ from the conjugate thiolate anion, $\mathrm{RS}^{-}$, followed by protonation of the latter, as illustrated in Scheme 1. In accord with this sequence where the first step is rate limiting, that is $k_{\text {off }}=k_{1}$, the reactivity order $\mathrm{NacTTC}^{-}>\mathrm{BnTTC}^{-}>\mathrm{PTTC}^{-} \sim \mathrm{MPTTC}$ at
Scheme 1. Proposed Sequence of Steps Leading to TTC Decay in Aqueous Media

$$
\begin{gathered}
\mathrm{RS}^{-\mathrm{CS}_{2}-} \underset{k_{2}}{\stackrel{k_{1}}{\rightleftarrows}} \mathrm{RS}^{-}+\mathrm{CS}_{2} \\
\mathrm{RS}^{-}+\mathrm{H}^{+} \stackrel{K_{a}^{-1}}{\rightleftharpoons} \mathrm{RSH}
\end{gathered}
$$

$\mathrm{pH} 7.4$ is roughly antiparallel to the increasing basicity of the thiolate anion $\mathrm{RS}^{-}$as reflected in $\mathrm{p} K_{\mathrm{a}}$ values of the respective thiols (RSH) (SI Table S1). ${ }^{12-16}$

In other words, the more basic thiolate ions are slower to dissociate from the $\mathrm{CS}_{2}$ electrophile. However, one might expect a positive value of $\Delta S^{\ddagger}$ for unimolecular dissociation of the RS-CS bond illustrated in the first step of Scheme 1, but that was not the case for $\mathrm{PTTC}^{-}, \mathrm{MPTTC}^{-}$, or NacTTC ${ }^{-}$. One possible explanation for the observed negative $\Delta S^{\ddagger}$ values would be a pathway involving concerted protonation of the exiting thiolate group by a general acid (solvent or buffer conjugate acid). However, no general acid catalysis was observed and protonation by $\mathrm{H}_{2} \mathrm{O}$ itself would generate hydroxide ion, which would be unfavorable. Thus, a more likely explanation for a negative entropy of activation draws from solvent reorganization as the negative charge delocalized over the $-\mathrm{CS}_{2}^{-}$functional group becomes localized on the thiolate ion at the transition state (Scheme 2).

Scheme 2. Solvation Reorganization upon $\mathrm{CS}_{2}$ Dissociation from a $\mathrm{TTC}^{-}$Anion

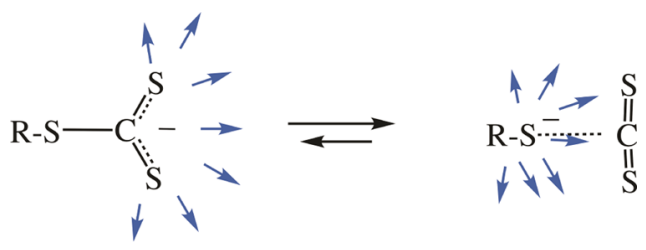

Formation of Trithiocarbonates. Physiologically, thiols are likely targets in the action of $\mathrm{CS}_{2}$ either as a toxin or in potential bioregulatory or therapeutic roles. ${ }^{1}$ For example, modification of a key protein thiol by the formation of trithiocarbonate would be expected to have profound effects on that protein's activity. The "on" reaction noted above is, of course, the formation of the $\mathrm{TTC}^{-}$adduct from the parent thiol plus $\mathrm{CS}_{2}$. The goal in this section is to examine the dynamics of trithiocarbonate formation with cysteine and several cysteine derivatives, including glutathione, in greater detail.

Figure 3 illustrates the temporal spectrum changes that occur rapidly after stopped-flow mixing of a solution containing excess cysteine $[\mathrm{CysSH}]$ with a second solution containing $\mathrm{CS}_{2}$ in pH 7.4 aqueous buffer at $37^{\circ} \mathrm{C}$. Very similar spectral changes were shown to result from the reactions of $\mathrm{CS}_{2}$ with (respectively) $N$-acetylcysteine (NacSH), glutathione (GSH, SI Figure S6), and cysteine methyl ester ( $\mathrm{MecSH}$, SI Figure S7). In each case, the appearance of the spectrum characteristic of a $\mathrm{TTC}^{-}$anion (eq 7) followed an exponential rise as seen in the figure inset. 


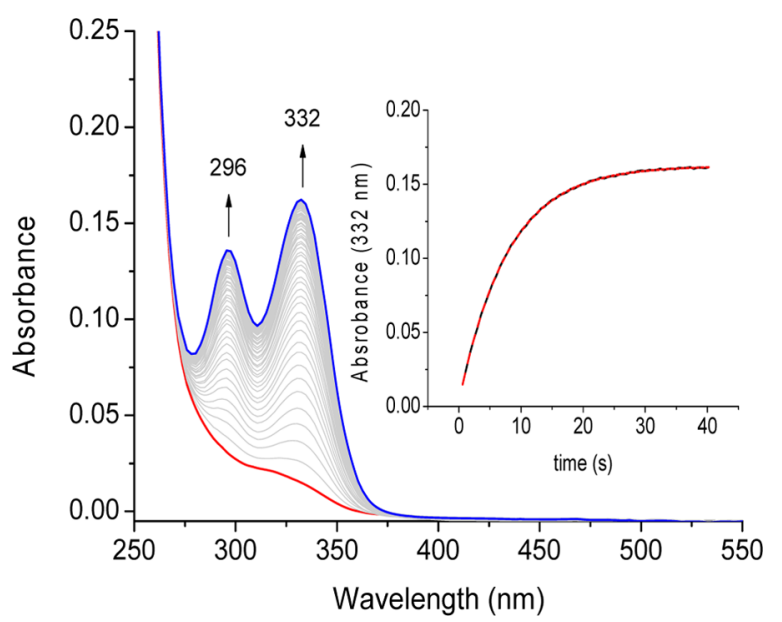

Figure 3. Temporal absorption spectra recorded over a period of $60 \mathrm{~s}$ of a solution prepared by 1:1 stopped-flow mixing of aqueous solutions of cysteine and $\mathrm{CS}_{2}$ with spectra recorded every $0.6 \mathrm{~s}$. Concentrations after mixing: $[\mathrm{CysSH}]=5 \mathrm{mM},\left[\mathrm{CS}_{2}\right]=0.2 \mathrm{mM}$. Conditions: $T=37$ ${ }^{\circ} \mathrm{C}, \mathrm{pH}$ 7.4, [phosphate buffer] $=50 \mathrm{mM}, \mu=154 \mathrm{mM}$. Inset: absorbance change at $332 \mathrm{~nm}$.

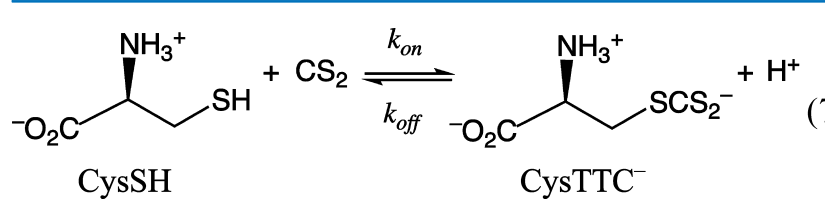

Figure 4 illustrates the absorption changes at $332 \mathrm{~nm}$ characteristic of formation of $\mathrm{CysTTC}^{-}$(eq 7) when a $\mathrm{pH} 7.4$

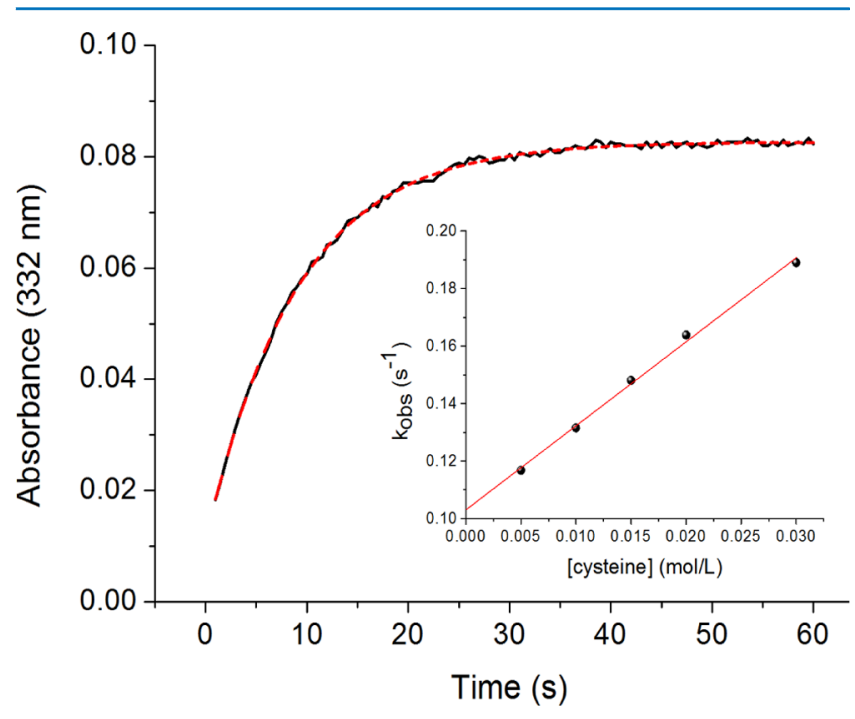

Figure 4. Exponential fit (red curve) of absorption changes at $332 \mathrm{~nm}$ (black dots) upon stopped-flow mixing of cysteine $(1 \mathrm{mM})$ with $\mathrm{CS}_{2}$ $(0.1 \mathrm{mM})$ in $37{ }^{\circ} \mathrm{C}$, $\mathrm{pH} 7.4$, aq phosphate buffer $\left(50 \mathrm{mM}, \mu_{\text {tot }}=154\right.$ $\mathrm{mM}$ ). Inset: plot of $k_{\text {obs }}$ values calculated from similar fits at various [CysSH]. Conditions after mixing: $\mathrm{pH} 7.4$, [buffer] $=100 \mathrm{mM}, T=37$ ${ }^{\circ} \mathrm{C}$, $[$ cysteine $]=5-30 \mathrm{mM},\left[\mathrm{CS}_{2}\right]=0.5 \mathrm{mM} . k_{\text {on }}=2.9 \mathrm{M}^{-1} \mathrm{~s}^{-1}$ (slope), $k_{\text {off }}=0.103 \mathrm{~s}^{-1}$ (intercept).

buffered solution of excess $\mathrm{CysSH}$ was mixed with a solution containing $\mathrm{CS}_{2}$ in the stopped-flow spectrometer. Under such "pseudo-first-order" conditions where $[\mathrm{CysSH}] \gg\left[\mathrm{CS}_{2}\right]$, the temporal absorption changes can be fit to a simple exponential function from which the observed first-order rate constant $k_{\text {obs }}$ was obtained. Under these conditions where the system is relaxing to equilibrium and $\mathrm{CS}_{2}$ is the limiting reactant, the relationship described by eq 8 holds true. ${ }^{17}$

$$
k_{\mathrm{obs}}=k_{\mathrm{off}}+k_{\mathrm{on}}[\mathrm{RSH}]
$$

Thus, when $\mathrm{RSH}=\mathrm{CysSH}$, a plot of $k_{\mathrm{obs}}$ versus [CysSH] should be linear with a slope equal to $k_{\text {on }}$ and an intercept equal to $k_{\text {off. }}$ The inset of Figure 4 is such a plot for the reaction of $\mathrm{CS}_{2}$ with excess $\mathrm{CysSH}$ in $37{ }^{\circ} \mathrm{C}, \mathrm{pH} 7.4$ buffered aqueous solutions from which the values $k_{\text {on }}=2.9 \pm 0.1 \mathrm{M}^{-1} \mathrm{~s}^{-1}$ and $k_{\text {off }}$ $=0.103 \pm 0.002 \mathrm{~s}^{-1}$ were determined. Plots similar to Figure 4 were generated for the reactions of glutathione $(\mathrm{GSH})$, cysteine methyl ester ( $\mathrm{MecSH}$ ), and $\mathrm{N}$-acetylcysteine (NacSH) (SI Figures $\mathrm{S} 6-\mathrm{S} 8)$, and the $k_{\mathrm{on}}$ and $k_{\text {off }}$ values so determined are summarized in Table 3. Notably, the values of $k_{\text {on }}$ and $k_{\text {off }}$ determined in $37{ }^{\circ} \mathrm{C}$, pH 7.4 solution for $\mathrm{NacSH}(0.606 \pm$ $0.008 \mathrm{M}^{-1} \mathrm{~s}^{-1}$ and $0.0138 \pm 0.001 \mathrm{~s}^{-1}$, respectively) can be compared to those $\left(0.7 \pm 0.2 \mathrm{M}^{-1} \mathrm{~s}^{-1}\right.$ and $\left.0.018 \pm 0.004 \mathrm{~s}^{-1}\right)$ obtained above by following the decay of $\mathrm{NacTTC}^{-}$under similar conditions. Given the different procedures and apparatus used in these two experiments, the agreement is quite good.

As noted above for several other TTC anions, the $k_{\text {off }}$ values reported in Table 3 for the cysteine derivatives decrease as the basicity of the $\mathrm{RS}^{-}$increases owing presumably to the higher $\mathrm{RS}-\mathrm{CS}_{2}{ }^{-}$bond strength through this series. The values of $k_{\text {on }}$ at $\mathrm{pH} 7.4$ show a similar decrease (hence, the ratio $k_{\text {on }} / k_{\text {off }}$ varies only modestly over this series). The behavior of $k_{\text {on }}$ would be consistent with the mechanism suggested by the microscopic reverse of Scheme 1. If $k_{\text {off }}=k_{1}$, then $k_{\text {on }}=k_{2}$ $f\left(\mathrm{H}^{+}\right)$, where $f\left(\mathrm{H}^{+}\right)=K_{\mathrm{a}} /\left(K_{\mathrm{a}}+\left[\mathrm{H}^{+}\right]\right)$. As the acidity of $\mathrm{RSH}$ $\left(K_{\mathrm{a}}\right)$ increases, more of the conjugate base thiolate $\mathrm{RS}^{-}$is available at $\mathrm{pH}$ 7.4. Thus, one would expect $k_{\text {on }}$ to increase. However, the nucleophilicity of $\mathrm{RS}^{-}$is likewise also decreasing over this series, so one might expect the rate constant $k_{2}$ for the nucleophilic attack of $\mathrm{RS}^{-}$on $\mathrm{CS}_{2}$ to correspondingly decrease in going from $\mathrm{NacS}^{-}$to $\mathrm{MeCysS}^{-}$, the two trends therefore countering each other. This may help account for a reactivity difference on only an order of magnitude between $\mathrm{NacSH}$ and $\mathrm{MeCysSH}$ at $\mathrm{pH} 7.4$ despite the much greater difference in $K_{\mathrm{a}}$ values.

SI Figure S9 displays Eyring plots of the $k_{\text {on }}$ and $k_{\text {off }}$ values determined in a similar manner for the reaction of $\mathrm{CysSH}$ with $\mathrm{CS}_{2}$ in $\mathrm{pH} 7.4$ buffered aqueous solution over the temperature range of $25-45{ }^{\circ} \mathrm{C}$. The apparent activation parameters for $k_{\text {on }}$ are $\Delta H^{\ddagger}=+84.3 \mathrm{~kJ} \mathrm{~mol}^{-1}$ and $\Delta S^{\ddagger}=+37.4 \mathrm{~J} \mathrm{~K}^{-1} \mathrm{~mol}^{-1}$, and those for $k_{\text {off }}$ are $\Delta H_{\text {off }}^{\ddagger}=+75.1 \mathrm{~kJ} \mathrm{~mol}^{-1}$ and $\Delta S_{\text {off }}^{\ddagger}=-21.7 \mathrm{~J}$ $\mathrm{K}^{-1} \mathrm{~mol}^{-1}$. Notably, $\Delta H^{\ddagger}$ for $k_{\text {off }}$ in this case are quite similar to that recorded above at $\mathrm{pH} 7.4$ for the decays of $\mathrm{PTTC}^{-}$, $\mathrm{MPTTC}^{-}$, and $\mathrm{NacTTC}^{-}$, but because $\Delta S^{\ddagger}$ remains negative in this case, it is less so than for the other three (SI Table S2). According to the proposed mechanism described in Scheme 1, $k_{\text {off }}=k_{1}$, so the apparent $\Delta H^{\ddagger}$ and $\Delta S^{\ddagger}$ for this step equal $\Delta H_{1}^{\ddagger}$ and $\Delta S_{1}^{\ddagger}$, respectively. The relationship is more complex for $k_{\text {on }}$ because it equals $k_{2} f\left(\mathrm{H}^{+}\right)$. If one were to make the rough approximation that, at $\mathrm{pH} 7.4,\left[\mathrm{H}^{+}\right] \gg K_{\mathrm{a}}$ then $k_{\text {on }} \cong$ $k_{2} K_{\mathrm{a}}\left[\mathrm{H}^{+}\right]^{-1}$ and then $\Delta H_{\text {on }}{ }^{\ddagger} \cong \Delta H_{2}^{\ddagger}+\Delta H_{\mathrm{a}}^{0}$ and $\Delta S_{\text {on }} \neq$ $\Delta S_{2}^{\ddagger}+\Delta S_{\mathrm{a}}{ }^{0}$. The values of $\Delta H_{\mathrm{a}}{ }^{0}$ and $\Delta S_{\mathrm{a}}{ }^{0}$ can be calculated as $+30.9 \mathrm{~kJ} / \mathrm{mol}$ and $-52 \mathrm{~J} \mathrm{~K}^{-1} \mathrm{~mol}^{-1}$, respectively, from the $\mathrm{pH}$ dependence of the $\mathrm{p} K_{\mathrm{a}}$ of cysteine (SI Figure S10). ${ }^{19}$ Thus, on the basis of this model, $\Delta H_{2}^{\ddagger} \cong 53 \mathrm{~kJ} \mathrm{~mol}^{-1}$ and $\Delta S_{2}^{\ddagger} \cong+89 \mathrm{~J}$ $\mathrm{K}^{-1} \mathrm{~mol}^{-1}$ for the reaction of $\mathrm{CysSH}$ with $\mathrm{CS}_{2}$.

Table 4 reports the results of analogous stopped-flow kinetics studies of the reactions of $\mathrm{CysSH}$ and $\mathrm{GSH}$ with $\mathrm{CS}_{2}$ to form 
Table 3. Values of $k_{\text {on }}$ and $k_{\text {off }}$ Determined Using a Stopped-Flow Kinetics Spectrophotometer for the Reactions of CysSH, $\mathrm{NacSH}, \mathrm{MecSH}$, and GSH with $\mathrm{CS}_{2}$ in $37^{\circ} \mathrm{C}, \mathrm{pH} 7.4$ Buffered Aqueous Solution ${ }^{a}$

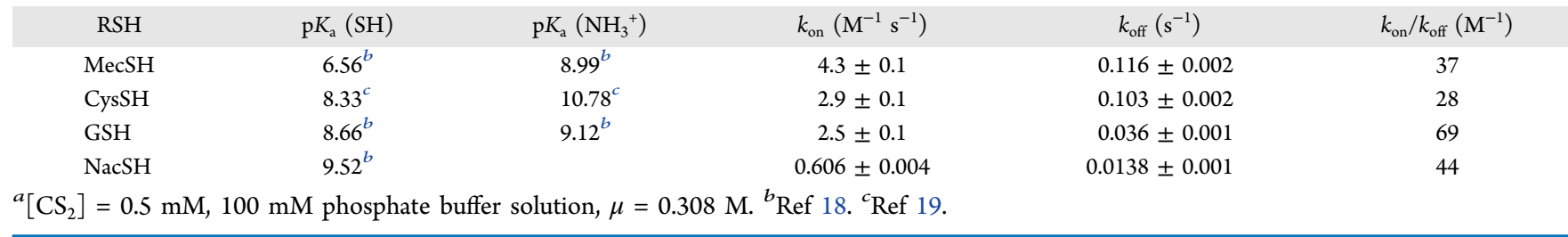

Table 4. Rate Constants Measured for Reaction between $\mathrm{CS}_{2}$ $(0.1 \mathrm{mM})$ and CysSH $(1-8 \mathrm{mM})$ or GSH $(1-8 \mathrm{mM})$ as a Function of $\mathrm{pH}$ at $37^{\circ} \mathrm{C}$ in Buffered Aqueous Solution

\begin{tabular}{cccccccc} 
& \multicolumn{3}{c}{ CysSH } & & \multicolumn{3}{c}{$\mathrm{GSH}$} \\
\cline { 2 - 3 } \cline { 7 - 8 } $\mathrm{pH}$ & $\begin{array}{c}k_{\text {on }} \\
\left(\mathrm{M}^{-1} \mathrm{~s}^{-1}\right)\end{array}$ & $\begin{array}{c}k_{\text {off }} \\
\left(\mathrm{s}^{-1}\right)\end{array}$ & $\begin{array}{c}k_{\text {on }} / k_{\text {off }} \\
\left(\mathrm{M}^{-1}\right)\end{array}$ & & $\begin{array}{c}k_{\text {on }} \\
\left(\mathrm{M}^{-1} \mathrm{~s}^{-1}\right)\end{array}$ & $\begin{array}{c}k_{\text {off }} \\
\left(\mathrm{s}^{-1}\right)\end{array}$ & $\begin{array}{c}k_{\text {on }} / k_{\text {off }} \\
\left(\mathrm{M}^{-1}\right)\end{array}$ \\
7.4 & 2.9 & 0.103 & 28 & & 2.5 & 0.036 & 69 \\
7.6 & 6.4 & 0.099 & 65 & & & \\
8.0 & 11.7 & 0.086 & 136 & & 8.7 & 0.039 & 224 \\
8.4 & 14.9 & 0.075 & 198 & & 13.7 & 0.036 & 380 \\
8.8 & 18.4 & 0.054 & 340 & & 23.5 & 0.034 & 692 \\
9.2 & 22.0 & 0.039 & 563 & & 32.5 & 0.034 & 956 \\
9.6 & 26.0 & 0.023 & 1129 & & 46.9 & 0.034 & 1340 \\
\hline
\end{tabular}

CysTTC $^{-}$and GTTC $^{-}$(eqs 7 and 9, respectively) at different $\mathrm{pH}$ values over the range of 7.4-9.6. The $k_{\text {obs }}$ values were determined for a range of different initial $\mathrm{CysSH}$ concentrations at each $\mathrm{pH}$, and linear plots of $k_{\text {obs }}$ versus [CysSH] similar to those shown in Figure 4 and SI Figures $\mathrm{S} 6-\mathrm{S} 8$ gave the $\mathrm{pH}$ dependent values of $k_{\text {on }}$ and $k_{\text {off }}$ Both systems show dramatic increases in $k_{\text {on }}$ at higher $\mathrm{pH}$ as anticipated from the simple mechanism proposed in Scheme 1. Consistent with the experiments for $\mathrm{PTTC}^{-}$and $\mathrm{BnTTC}^{-}$reported in Tables 1 and 2, the $k_{\text {off }}$ values for $\mathrm{GTTC}^{-}$are $\mathrm{pH}$-independent; however, this was not the case for CysTTC ${ }^{-}$, for which $k_{\text {off }}$ decreases by about a factor of four from $\mathrm{pH} 7.4$ to 9.6. We attribute this difference to the relative proximity of the protonated amine group $\left(\mathrm{NH}_{3}^{+}\right)$to the trithiocarbonate functionality in CysTTC $^{-}$. The resulting change in the inductive effect upon deprotonation of this group at higher $\mathrm{pH}$ should enhance the basicity of the thiolate, thus leading to slower dissociation of $\mathrm{CS}_{2}$. Although $\mathrm{GTTC}^{-}$has a similar amine, it is positioned further from the TTC functionality and its deprotonation would have a much smaller impact.<smiles>C[I+]#COC(=O)C(N)CCC(=O)NC(CSC(=S)[S-])C(=O)NCC(=O)[O-]</smiles>

Subsequent Reactions of CysTTC ${ }^{-}$and GTTC $^{-}$. Although the reaction of $\mathrm{CS}_{2}$ with cysteine initially showed the rapid appearance of new absorption bands at $\sim 295$ and 332 $\mathrm{nm}$ consistent with the formation of the trithiocarbonate CysTTC $^{-}$(eq 7), a much slower subsequent reaction was evidenced by further spectral changes (Figure 5) involving the disappearance of the bands at $\sim 295$ and $332 \mathrm{~nm}$ and the appearance of a new band at $270 \mathrm{~nm}$. The latter band can be

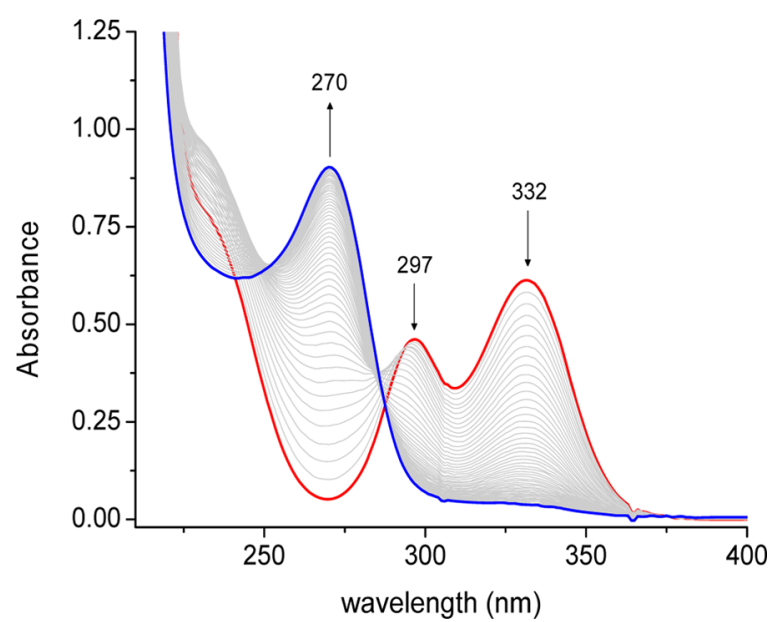

Figure 5. Spectral changes upon mixing $\mathrm{CS}_{2}(1 \mathrm{mM})$ with $\mathrm{CysSH}(1$ $\mathrm{mM})$ in $\mathrm{pH} 7.4$ aq phosphate buffer $(100 \mathrm{mM})$ at $37^{\circ} \mathrm{C}$ in a sealed cell indicating the slow transformation of $\mathrm{CysTTC}^{-}$(red spectrum) to TTCA (blue spectrum). Total time $=17 \mathrm{~h}$. Spectra recorded at $600 \mathrm{~s}$ intervals.

assigned to the cyclized compound thiazolidine-2-thionecarboxylate (TTCA, eq 10), ${ }^{9}$ which has been identified ${ }^{20,21}$ as a urinary excretion product from humans who have been exposed to $\mathrm{CS}_{2}$. The temporal decay at $332 \mathrm{~nm}$ and rise at 270 $\mathrm{nm}$ could be fit to exponential functions to give the respective first-order rate constants $5.2 \times 10^{-5}$ and $4.9 \times 10^{-5} \mathrm{~s}^{-1}$ in $\mathrm{pH}$ 7.4 aq phosphate buffer at $37{ }^{\circ} \mathrm{C}$ (SI Figure S11). However, inspection of the spectral changes shows the absence of isosbestic points, as well as an absorbance increase followed by a decrease of a shoulder at $\sim 230 \mathrm{~nm}$, which are clear indications that a transient intermediate species is formed. When the reaction was run with a very large excess of $\mathrm{CysSH}$ $\left(\left[\mathrm{CS}_{2}\right]=0.2 \mathrm{mM} ;[\mathrm{CysSH}]=10 \mathrm{mM}\right)$, the $k_{\mathrm{obs}}$ value measured was nearly the same $\left(5.8 \times 10^{-5} \mathrm{~s}^{-1}\right)$. Thus, it appears that this slow cyclization process is unimolecular and does not involve the reaction of free CysSH.<smiles>CC(C)C(=O)[C@H]([NH3+])CSC(=S)[CH-][C@@H]([NH3+])C(=O)[O-]</smiles>

CysTTC

TTCA

The reaction of cysteine $(10 \mathrm{mM})$ and $\mathrm{CS}_{2}(10 \mathrm{mM})$ was further studied in a buffered phosphate deuterium oxide solution (prepared with anhydrous $\mathrm{Na}_{3} \mathrm{PO}_{4}$ plus $\mathrm{D}_{2} \mathrm{O}, \mathrm{pD} 7.5$ ) to characterize more thoroughly the formation of TTCA. DCl solution ( 35 wt $\%$ in $\mathrm{D}_{2} \mathrm{O}$ ) was used to correct the $\mathrm{pD}$. The 
reaction was run for $24 \mathrm{~h}$ at $37{ }^{\circ} \mathrm{C}$. A small aliquot of the product solution was used to check the electronic spectrum, which showed the presence of a single and intense absorption band at $271 \mathrm{~nm}$ (SI Figure S12), indicating the formation of the cyclic compound because unreacted cysteine and oxidized cysteine products, such as cystine, have no strong absorption bands in this wavelength range. The ${ }^{1} \mathrm{H}$ NMR spectrum of the product solution (SI Figure S13) showed not only resonances belonging to unreacted cysteine but also two groups of proton resonances at $3.67-3.63 \mathrm{ppm}\left(\mathrm{S}-\mathrm{CH}_{2}\right.$, doublet of doublets) and 3.92-3.89 ( $\mathrm{CH}$, broad doublet of doublets) attributed by van Doorn et al. to the hydrogens of TTCA. ${ }^{22}$

GTTC $^{-}$formed by the relatively rapid reaction of GSH with $\mathrm{CS}_{2}$ also goes through a very slow transformation to a new species reported to be TTCA (SI Figure S14). However, similar spectral changes/secondary reaction was not seen with 3trithiocarbonatopropionate $\left(\mathrm{PTTC}^{-}\right.$) but was observed with 3trithiocarbonatopropylamine and thus an amine functionality appears to be required. This is not simply the transfer of $\mathrm{CS}_{2}$ from the thiolate to the amine to form a dithiocarbamate $\left(\mathrm{DTC}^{-}\right)$analogue because the spectrum formed by the reaction of aqueous base and glycine displays bands at 253 and $284 \mathrm{~nm}$ (data not shown) typical of DTC anions and very different from the characteristic of TTCA. The mechanism(s) of these transformations are the subject of continuing investigation.

\section{SUMMARY}

We have described the kinetics of the formation and decay of trithiocarbonate derivatives formed by the reactions of carbon disulfide and various thiols ( $\mathrm{RSH}$ ) under physiologically relevant conditions (near-neutral $\mathrm{pH}, 37^{\circ} \mathrm{C}$ ). Rates of $\mathrm{TTC}^{-}$ formation are strongly dependent on solution $\mathrm{pH}$, indicating that the rate-limiting step involves the reaction of the thiolate anion RS- with the electrophilic $\mathrm{CS}_{2}$ substrate. Rates of TTC decay are $\mathrm{pH}$-independent, consistent with microscopic reversibility. The relative decay rates have a reverse correlation to the basicity of the $\mathrm{RS}^{-}$anions as expected if simple dissociation of $\mathrm{CS}_{2}$ is rate determining, as illustrated by the qualitative reaction coordinate diagram shown in Figure 6. At $\mathrm{pH} 7.4$, glutathione and cysteine react with $\mathrm{CS}_{2}$ at similar rates, and in both cases, the resulting $\mathrm{TTC}^{-}$anions undergo slow cyclization reactions to a cyclized species identified previously as 2-thiothiazolidine-4-carboxylic acid. As noted above, the latter has been found to be urinary excretion products from individuals exposed to toxic levels of carbon disulfide. Similar reactions with protein thiols could lead to irreversible modifications of such targets as well as releasing an equivalent of $\mathrm{H}_{2} \mathrm{~S}$.

The present data do not resolve the question whether $\mathrm{CS}_{2}$ might serve some type of bioregulatory role. Although thiols would appear to be logical targets for this electrophile, it is clear that the rates and equilibrium constants for $\mathrm{TTC}^{-}$adduct formation are many orders of magnitude smaller than those for reactions of NO with heme proteins, the best characterized targets of that SMB. ${ }^{23,24}$ It appears likely that any such bioregulatory relevant sites for $\mathrm{CS}_{2}$ would have higher binding constants, for example, an activated thiolate protein, where the $\mathrm{TTC}^{-}$anion is stabilized by other intramolecular interactions. Another could be a metal center because it is well established that transition-metal ions activate $\mathrm{CS}_{2}$ toward reaction with coordinated nucleophiles and insertion into metal-ligand bonds, owing to the strong bonding of the 1,1-dithiolate $\left(-\mathrm{CS}_{2}^{-}\right)$functionality as a ligand. Such reactivity has been

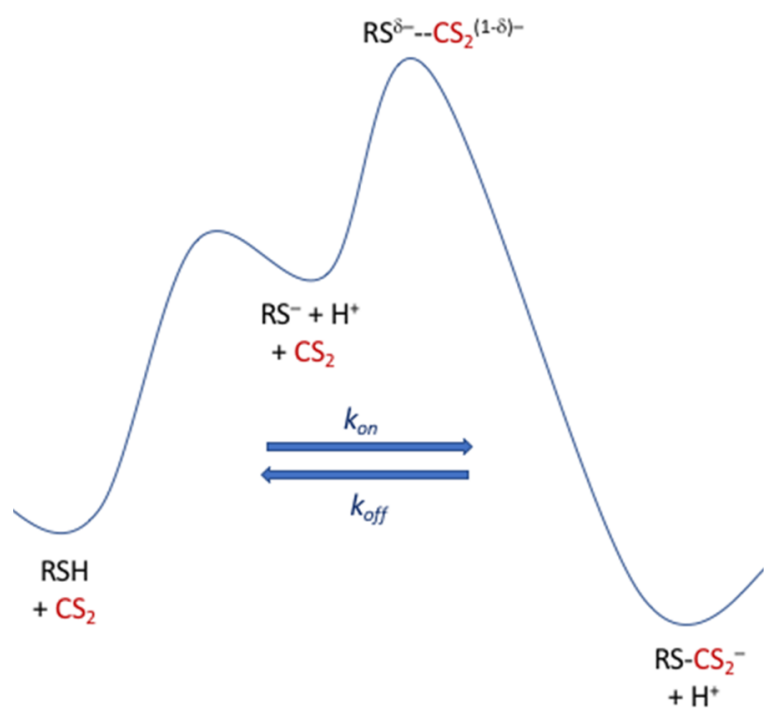

Figure 6. Qualitative reaction coordinate diagram for the formation $\left(k_{\text {on }}\right)$ and decay $\left(k_{\text {off }}\right)$ of trithiocarbonate anions $\left(\mathrm{RSCS}_{2}^{-}\right)$from the respective thiols plus carbon disulfide. According to Scheme $1, \mathrm{TTC}^{-}$ decay is independent of $\mathrm{pH}\left(k_{\text {off }}=k_{1}\right)$, whereas the forward reaction is strongly $\mathrm{pH}$-dependent owing to the $\mathrm{RSH} \rightleftharpoons \mathrm{RS}^{-}+\mathrm{H}^{+}$equilibrium.

reported for metal-sulfur bonds ${ }^{25,26}$ as well as with alkoxide, ${ }^{27}$ amine, ${ }^{28,29}$ and (even) phosphine ${ }^{30}$ ligands. Given the relatively high cytosolic concentrations of $\mathrm{GSH}^{31}$ and plasma-based protein sulfhydryls, ${ }^{32}$ the reversible formation of unstabilized TTCs may play a role in $\mathrm{CS}_{2}$ transport.

\section{EXPERIMENTAL SECTION}

Materials. Except where otherwise noted, all materials were of analytical or reagent grade and were used without further purification. N-Acetyl-L-cysteine ( $\geq 99 \%$, TLC), 3-mercaptopropionic acid ( $\geq 99 \%)$, L-cysteine $(97 \%)$, glycine $(\geq 98.5 \%)$, and reduced L-glutathione (98\%) were purchased from SigmaAldrich. Carbon disulfide (ACS Reagent Grade, $\geq 99.9 \%$ ), benzyl mercaptan (Alfa Aesar, 99\%), potassium hydroxide, sodium hydroxide, and mono- and dibasic sodium phosphate and sodium chloride used to prepare buffers were purchased from Fisher Scientific.

Synthesis of TTCs. Sodium 3-(Trithiocarbonato)propionate ( $\left.\mathrm{Na}_{2}[\mathrm{PTTC}]\right)$. This species had been generated as an intermediate in the preparation of a corresponding trithiocarbonate ester. ${ }^{33}$ A round-bottom flask was charged with pentane and $\mathrm{CS}_{2}(30 \mathrm{~mL}$ each $)$ plus a stir bar and then was cooled to approximately $0-5{ }^{\circ} \mathrm{C}$ with an ice bath and purged with inert gas. During rapid stirring, finely ground $\mathrm{NaOH}(3.09 \mathrm{~g}, 77.4 \mathrm{mmol})$ was added to the flask under inert gas. Sufficient water was added to solubilize the hydroxide (1-3 $\mathrm{mL}$ ), and to the resulting base solution, 3-mercaptopropionic acid $(4.11 \mathrm{~g}, 38.7 \mathrm{mmol})$ in diethyl ether $(10 \mathrm{~mL})$ was added dropwise over the course of a few minutes. A deep yellow powder immediately began to precipitate. The reaction was allowed to warm to room temperature, and stirring was continued for $6-12 \mathrm{~h}$. The solid was collected via filtration and rinsed with cold $\mathrm{Et}_{2} \mathrm{O}$. The yield was $3.68 \mathrm{~g}$ (37\%). The product proved to be soluble only in methanol or water; however, attempts to recrystallize from these solvents resulted in decomposition. The optical spectrum of the initial product in $\mathrm{pH} 7.4$ water displayed bands at $\lambda_{\max }=303$ and $332 \mathrm{~nm}$ with an extinction coefficient at $332 \mathrm{~nm}\left(8650 \mathrm{M}^{-1} \mathrm{~cm}^{-1}\right)$ close to 
those previously observed for alkyl TTCs. ${ }^{21}$ The infrared spectrum and CHN analysis are consistent with a hydrated sample. The solid is rather odorous. The compounds were kept in a freezer for long-term storage. Infrared spectrum: (attenuated total reflection in $\mathrm{cm}^{-1}$ ) selected bands 989, 879 $(\nu, \mathrm{C}-\mathrm{S}), 1148(\mathrm{C}=\mathrm{S}), 1395(\delta, \mathrm{C}-\mathrm{O}), 1555(\nu, \mathrm{C}-\mathrm{O}), 1655$ $(\delta, \mathrm{O}-\mathrm{H}), 3300(\nu, \mathrm{O}-\mathrm{H})$. Anal.: (calculated values for $\mathrm{C}_{4} \mathrm{H}_{4} \mathrm{Na}_{2} \mathrm{~S}_{3} \cdot 2 \mathrm{H}_{2} \mathrm{O}$ in parentheses): C, 18.1 (18.32); $\mathrm{H}, 2.8$ (3.07).

Triethylammonium ( $\mathrm{N}$-Acetylcysteine)trithiocarbonate ([HNEt $\left.\left.{ }_{3}\right][\mathrm{NaCTC}]\right)$. To an ice-cold $\left(0-5{ }^{\circ} \mathrm{C}\right)$ flask containing diethyl ether $(30 \mathrm{~mL})$ and triethylamine $(3.72 \mathrm{~g}, 36.8 \mathrm{mmol})$ under inert atmosphere, a $3 \mathrm{~g}$ portion of $N$-acetylcysteine (18.4 mmol) was added. Dimethylformamide (2-3 drops) was added to solubilize the $\mathrm{N}$-acetylcysteine, after which $\mathrm{CS}_{2}(1.90 \mathrm{~g}, 25$ $\mathrm{mM}$ ) was added dropwise, resulting in rapid separation of an insoluble, viscous, translucent, golden oil. This oil was separated from the solvent by decanting and was dried in vacuo for several days at elevated temperature $\left(\sim 40{ }^{\circ} \mathrm{C}\right)$. The oil was then dissolved in ethanol, heated gently, and the resulting solution stirred vigorously. Vacuum removal of the ethanol resulted again in a golden oil. This product was stored in a freezer. Optical spectrum: $\lambda_{\max }=302$ and $333 \mathrm{~nm}$ in $\mathrm{pH} 7.0$ water with a molar extinction coefficient of $\sim 8400 \mathrm{M}^{-1} \mathrm{~cm}^{-1}$ at the latter wavelength. ESI-MS (neg. mode) (75\% ACN, 25\% $\left.\mathrm{H}_{2} \mathrm{O}\right)$ : Anion predicted $\left(+\mathrm{H}^{+}\right), 237.96 \mathrm{~m} / z$; found, $237.94 \mathrm{~m} / z$, $259.89 \mathrm{~m} / z\left(+\mathrm{Na}^{+}\right), 339.04 \mathrm{~m} / z\left(+\mathrm{TEAH}^{+}\right)$. Also observed, $162.17 \mathrm{~m} / z$ ( $\mathrm{N}$-acetylcysteine, impurity/decomposition). Anal. (calculated values for $\mathrm{C}_{18} \mathrm{H}_{39} \mathrm{~N}_{3} \mathrm{O}_{3} \mathrm{~S}_{3}$ in parentheses): $\mathrm{C}, 48.0$ (48.95); H, 8.22 (8.90); N, 9.39 (9.51).

Potassium Benzyl Trithiocarbonate (K[BnTTC]). The preparation was adapted from a known procedure. ${ }^{5} \mathrm{~A}$ roundbottom flask was charged with a magnetic stirring bar, diethyl ether $(30 \mathrm{~mL})$, and carbon disulfide $(10 \mathrm{~mL})$. The solution was cooled to $0-5{ }^{\circ} \mathrm{C}$ with an ice bath and then purged with nitrogen. Finely ground $\mathrm{KOH}(2.00 \mathrm{~g}, 35.6 \mathrm{mmol})$ was added and then benzyl mercaptan $(5 \mathrm{~mL}, 5.29 \mathrm{~g}, 42.6 \mathrm{mmol})$ was added to this cloudy mixture over a period of $2 \mathrm{~min}$. The resulting solution rapidly became yellow and cloudy to give a chalky precipitate. This mixture was stirred for an additional 3 h. The solid product was collected by filtration and washed with diethyl ether and cold ethanol $(4 \times 10 \mathrm{~mL})$. The solid was then added to a flask containing $150 \mathrm{~mL}$ of $\mathrm{Et}_{2} \mathrm{O}$ and collected by filtration again to remove excess dimethylformamide. Recrystallization from a 50/50 mixture of ethanol and acetonitrile gave a deep yellow, mildly odorous powder that was dried in vacuo and stored in a freezer. The yield was $4.58 \mathrm{~g}(54 \%) . K[$ BnTTC] decomposes when dissolved in water or water/alcohol mixtures to give highly odorous product(s). $\mathrm{CHN}$ anal. (calculated values for $\mathrm{C}_{8} \mathrm{H}_{7} \mathrm{KS}_{3}$ in parentheses): $\mathrm{C}, 39.8$ (40.3); $\mathrm{H}, 2.84$ (2.96). Optical spectrum: $\lambda_{\max }=302$ and $332 \mathrm{~nm}$ in $\mathrm{pH} 7.4$ water (extinction coefficient of $\sim 9300 \mathrm{M}^{-1} \mathrm{~cm}^{-1}$ at the latter wavelength). (Note: Benzyl mercaptan has a particularly unpleasant odor and is toxic. Proper environmental controls must be observed when handling this liquid.)

Kinetics Methods. Phosphate buffers were prepared using mono- and dibasic sodium phosphate and sodium chloride (to maintain ionic strength). Nanopure water ( $\geq 18$ megohm) was obtained from a Barnstead Nanopure II system and used in solution preparations.

The rates of the TTC decompositions were determined by monitoring temporal spectral changes on a Shimadzu UV-2401 spectrophotometer with UVProbe kinetics software. The reaction cell was a septum-capped, sealable quartz cuvette with a $1.0 \mathrm{~cm}$ path length and an approximate volume of 4.80 $\mathrm{mL}$. The cells were thermostated $\left( \pm 0.2{ }^{\circ} \mathrm{C}\right)$ at the desired reaction temperature, and the solutions were stirred with a Starna "Spinnette" stirrer. Septum-sealed cells containing the buffer solution of interest temperature equilibrated $(7-10 \mathrm{~min})$ under the desired conditions (typically $37^{\circ} \mathrm{C}$ ). A small amount of the solid TTC salt $(5-10 \mathrm{mg})$ was then added to a vial containing 3-5 $\mathrm{mL}$ of buffer to prepare a stock solution. A 100 $\mu \mathrm{L}$ aliquot of this stock solution was then syringed into the thermostated cuvette. The volumes were chosen to minimize the headspace in the cuvette. Data acquisition was initiated after an estimated dead time of 60-90 s.

Kinetics of the reactions of $\mathrm{CS}_{2}$ with various thiols to examine the rates of TTC formation were generally performed using an Applied Photophysics SX.19MV stopped-flow UVvisible spectrophotometer with photodiode array (temporal spectra) or a photomultiplier tube (single wavelength) detector. Aqueous buffered solutions of the thiol $(\mathrm{RSH})$ and $\mathrm{CS}_{2}$ were loaded into Hamilton salt syringes (\#1725 AD-SL), which were attached to the mixing block of the spectrophotometer and sealed from the outside atmosphere by a three-way valve. These syringes were maintained at the desired temperature (generally $37^{\circ} \mathrm{C}$ unless otherwise noted) by a circulating water bath. The connector tubing and observation cell were purged with the sample solution by filling and emptying the drive syringes $3 \times$ prior to data acquisition. Stopped-flow mixing of the two solutions initiated the reaction. The entire unit was controlled with "Applied Photophysics Pro-Data SX" software. Only simultaneous symmetric mixing was used (1:1 dilution).

Kinetics data were processed using Igor Pro 6.37 software by WaveMetrics, Inc., and Prism 7 by GraphPad Software, Inc. For global fittings of equilibrium analyses and determination of back-reaction values, a DynaFit (BioKin Ltd) nonlinear leastsquares regression program was used.

Computational Studies. All density functional theory (DFT) computations were performed using Gaussian'09 software packages. Optimizations were performed using Kohn-Sham DFT with the hybrid M06-2X exchangecorrelation functional and the $6-311+G(d, p)$ basis set. No symmetry restriction was imposed, and implicit solvent effects were included using PCM (solvent = water) methods, as implemented in Gaussian 09. Vibrational frequency calculations were performed at the same level of theory to verify that no imaginary frequencies were present and to ensure the true local minima energies. Single-point energy and time-dependent DFT calculations were performed using the M062X/6-311+G(3df,3pd) level of theory.

Analysis of $\mathrm{CS}_{2}$ Release. This procedure was similar to that described by Schwach and Nyanzi ${ }^{34}$ and to that used in this laboratory to detect $\mathrm{CS}_{2}$ released by the photolysis of $\mathrm{CdSe}$ quantum dots surface decorated with 1,1-dithiooxalate ${ }^{7}$ and for the $\mathrm{CS}_{2}$ released in the thermal reactions of dithiocarbamate salts. $^{8}$

\section{ASSOCIATED CONTENT}

\section{Supporting Information}

The Supporting Information is available free of charge on the ACS Publications website at DOI: 10.1021/acsomega.7b01206.

Additional documentation (2 tables and 11 figures) of the studies (PDF) 


\section{AUTHOR INFORMATION}

\section{Corresponding Author}

*E-mail: ford@chem.ucsb.edu.

\section{ORCID}

Peter C. Ford: 0000-0002-5509-9912

\section{Present Addresses}

${ }^{\ddagger}$ Division of Pulmonary, Allergy, and Critical Care Medicine, Pittsburgh Heart, Lung, Blood, and Vascular Medicine Institute, University of Pittsburgh, Pennsylvania 15213, United States (A.W.D.).

${ }^{\S}$ CAPES Foundation, Ministry of Education of Brazil, Brasilia, DF 70040-020, Brazil (M.L.S.).

\section{Author Contributions}

${ }^{\dagger}$ M.L.S. and A.W.D. contributed equally.

\section{Notes}

The authors declare no competing financial interest.

Carbon disulfide is toxic at high exposures, and long periods of modest exposure have been associated with a number of health conditions. $\mathrm{CS}_{2}$ and $\mathrm{CS}_{2}$-generating compounds should be handled and stored with care.

\section{ACKNOWLEDGMENTS}

This work was supported by grants to PCF from the Chemistry Division of the United States National Science Foundation (CHE-1405062 and CHE-1565702). The authors acknowledge the UCSB Academic Senate Research Committee for seed money in support of this research. They also acknowledge support from the Center for Scientific Computing from the CNSI, MRL: NSF MRSEC (DMR-1121053) and NSF CNS0960316. M.L.S. thanks CAPES (Coordenação de Aperfeiçoamento de Pessoal de nível Superior), process 99999.000902/ 2015-02, for a postdoctoral fellowship.

\section{REFERENCES}

(1) DeMartino, A. W.; Zigler, D. F.; Fukuto, J. M.; Ford, P. C. Carbon disulfide. Just toxic or also bioregulatory and/or therapeutic? Chem. Soc. Rev. 2017, 46, 21-39.

(2) Fukuto, J. M.; Carrington, S. J.; Tantillo, D. J.; Harrison, J. G.; Ignarro, L. J.; Freeman, B. A.; Chen, A.; Wink, D. A. Small Molecule Signaling Agents: The Integrated Chemistry and Biochemistry of Nitrogen Oxides, Oxides of Carbon, Dioxygen, Hydrogen Sulfide, and Their Derived Species. Chem. Res. Toxicol. 2012, 25, 769-793.

(3) Gelbke, H.-P.; Göen, T.; Mäurer, M.; Sulsky, S. I. A Review of Health Effects of Carbon Disulfide in Viscose Industry and a Proposal for an Occupational Exposure Limit. Crit. Rev. Toxicol. 2009, 39, 1126.

(4) Vitali, B.; Ndagijimana, M.; Maccaferri, S.; Biagi, E.; Guerzoni, M. E.; Brigidi, P. An in Vitro Evaluation of the Effect of Probiotics and Prebiotics on the Metabolic Profile of Human Microbiota. Anaerobe 2012, 18, 386-391.

(5) Carta, F.; Akdemir, A.; Scozzafava, A.; Masini, E.; Supuran, C. T. Xanthates and Trithiocarbonates Strongly Inhibit Carbonic Anhydrases and Show Antiglaucoma Effects in Vivo. J. Med. Chem. 2013, 56, 4691-4700.

(6) Venter, J. A.; Vermaak, M. K. G. Mechanisms of trithiocarbonate adsorption: A flotation perspective. Miner. Eng. 2008, 21, 1044-1049.

(7) Bernt, C. M.; Burks, P. T.; DeMartino, A. W.; Pierri, A. E.; Levy, E. S.; Zigler, D. F.; Ford, P. C. Photocatalytic Carbon Disulfide Production via Charge Transfer Quenching of Quantum Dots. J. Am. Chem. Soc. 2014, 136, 2192-2195.

(8) DeMartino, A. W.; Souza, M. L.; Ford, P. C. Uncaging Carbon Disulfide. Delivery Platforms for Potential Pharmacological Applications: A Mechanistic Approach. Chem. Sci. 2017, 8, 7186-7196.
(9) van Doorn, R.; Henderson, P. T.; Vanhoorne, M.; Vertin, P. G.; Leijdekkers, J. M. Determination of thio compounds in urine of workers exposed to carbon disulfide. Arch. Environ. Health 1981, 36, 289-297.

(10) Domergue, J.; Lison, D.; Haufroid, V. No evidence of cardiovascular toxicity in workers exposed below $5 \mathrm{ppm}$ carbon disulfide. Int. Arch. Occup. Environ. Health 2016, 89, 835-845.

(11) Shankaranarayana, M. L.; et al. The Electronic Spectra of some Derivatives of Xanthic, Dithiocarbamic and trithiocarbonic Acids. Acta Chem. Scand. 1965, 19, 1113-1119.

(12) The SH group $\mathrm{pK}_{\mathrm{s}}$ 's of $\mathrm{N}$-acetylcysteine (NacSH) and 3mercaptoproprionic acid (3-MPA) are 9.5 and 10.3, respectively (refs 13 and 14). Benzyl mercaptan is not water soluble, but a value of 9.46 has been reported (ref 15) although since mercaptans are typically $\sim 5.5 \mathrm{p} K_{\mathrm{a}}$ units more acidic than the corresponding alcohols and benzyl alcohol has a $\mathrm{p} K_{\mathrm{a}}$ of 15.4 (ref 16), we would have estimated a slightly higher $\mathrm{p} K_{\mathrm{a}}$ of $\sim 9.9$.

(13) Burner, U.; Obinger, C. Transient-State and Steady-State Kinetics of the Oxidation of Aliphatic and Aromatic Thiols by Horseradish Peroxidase. FEBS Lett. 1997, 411, 269-274.

(14) Srinivasan, U.; Mieyal, P. A.; Mieyal, J. J. pH Profiles Indicative of Rate-Limiting Nucleophilic Displacement in Thioltransferase Catalysis. Biochemistry 1997, 36, 3199-3206.

(15) Kreevoy, M. M.; Harper, E. T.; Duvall, R. E.; Wilgus, H. S., III; Ditsch, L. T. Inductive effects on the acid dissociation constants of mercaptans. J. Am. Chem. Soc. 1960, 82, 4899-4902.

(16) Cao, Z.-C.; Luo, F.-X.; Shi, W.-J.; Shi, Z.-J. Direct Borylation of Benzyl Alcohol and Its Analogues in the Absence of Bases. Org. Chem. Front. 2015, 2, 1505-1510.

(17) Atkins, P. W.; DePaula, J. Physical Chemistry, 9th ed.; W. H. Freeman \& Co: New York, 2010; p 797.

(18) Dean, J. A. Lange's Handbook of Chemistry, 15th ed.; McGrawHill Companies: New York, 1998.

(19) Sharma, V. K.; Casteran, F.; Millero, F. J.; De Stefano, C. Dissociation Constants of Protonated Cysteine Species in $\mathrm{NaCl}$ Media. J. Solution Chem. 2002, 31, 783-792.

(20) Weiss, T.; Hardt, J.; Angerer, J. Determination of Urinary 2Thiazolidinethione-4-Carboxylic Acid after Exposure to Alkylene Bisdithiocarbamates Using Gas Chromatography-Mass Spectrometry. J. Chromatogr. B: Biomed. Sci. Appl. 1999, 726, 85-94.

(21) Amarnath, V.; Amarnath, K.; Graham, D. G.; Qi, Q.; Valentine, H.; Zhang, J.; Valentine, W. M. Identification of a New Urinary Metabolite of Carbon Disulfide Using an Improved Method for the Determination of 2-Thioxothiazolidine-4-Carboxylic Acid. Chem. Res. Toxicol. 2001, 14, 1277-1283.

(22) van Doorn, R.; Delbressine, L. P. C.; Leijdekkers, Ch.-M.; Vertin, P. G.; Henderson, P. Th. Identification and determination of 2 thiothiazolidine-4-carboxylic acid in urine of workers exposed to carbon disulfide. Arch. Toxicol. 1981, 47, 51-58.

(23) Ford, P. C. Reactions of NO and Nitrite with Heme Models and Proteins. Inorg. Chem. 2010, 49, 6226-6239.

(24) Montfort, W. R; Wales, J. A.; Weichsel, A. Structure and Activation of Soluble Guanylyl Cyclase, the Nitric Oxide Sensor. Antioxid. Redox Signaling 2017, 26, 107-121.

(25) Tang, K.; Jin, X.; Tang, Y. Insertion of $\mathrm{CS}_{2}$ into M-S bonds and its Application in Synthesis of Clusters. Rev. Heteroat. Chem. 1996, 15, 83-114.

(26) Hartmann, N. J.; Wu, G.; Hayton, T. W. Activation of $\mathrm{CS}_{2}$ by a "masked" terminal nickel sulfide. Dalton Trans. 2016, 45, 1450814510.

(27) Bezougli, I. K.; Bashall, A.; McPartlin, M.; Mingos, D. M. P. Insertion of $\mathrm{CS}_{2}$ into the Group 2 metal-alkoxide bonds of $\left[\left\{\mathrm{M}(\mathrm{OR})_{2}\right\}_{\mathrm{n}}\right]\left(\mathrm{M}=\mathrm{Mg}, \mathrm{Ca}, \mathrm{Sr}\right.$, or Ba; $\mathrm{R}=\mathrm{Et}$ or $\left.\mathrm{Pr}^{\mathrm{i}}\right)$. J. Chem. Soc., Dalton Trans. 1998, 2671-2678.

(28) Yih, K.-H.; Chen, S.-C.; Lin, Y.-C.; Lee, G.-H.; Wang, Y. New syntheses of $\left[\mathrm{Et}_{4} \mathrm{~N}\right]\left[\left(\mathrm{C}_{5} \mathrm{H}_{10} \mathrm{NCS}\right) \mathrm{M}(\mathrm{CO})_{4}\right](\mathrm{M}=\mathrm{Cr}$, Mo and $\mathrm{W})$; Insertion reaction of carbon disulfide into the metal-nitrogen bond. $J$. Organomet. Chem. 1995, 494, 149-155. 
(29) Lane, A. C.; Vollmer, M. V.; Laber, C. H.; Melgarejo, D. Y.; Chiarella, G. M.; Fackler, J. P.; Yang, X.; Baker, G. A.; Walensky, J. R. Multinuclear copper(I) and silver(I) amidinate complexes: Synthesis, luminescence, and $\mathrm{CS}_{2}$ insertion reactivity. Inorg. Chem. 2014, 53, $11357-11366$.

(30) Ghiassi, K. B.; Walters, D. T.; Aristov, M. M.; Loewen, N. D.; Berben, L. A.; Rivera, M.; Olmstead, M. M.; Balch, A. L. Formation of a Stable Complex, $\mathrm{RuCl}_{2}\left(\mathrm{~S}_{2} \mathrm{CPPh}_{3}\right)\left(\mathrm{PPh}_{3}\right)_{2}$, containing an unstable zwitterion from the reaction of $\mathrm{RuCl}_{2}\left(\mathrm{PPh}_{3}\right)_{3}$ with carbon disulfide. Inorg. Chem. 2015, 54, 4565-4573.

(31) Smith, C. V.; Jones, D. P.; Guenthner, T. M.; Lash, L. H.; Lauterburg, B. H. Compartmentation of glutathione: Implications for the study of toxicity and disease. Toxicol. Appl. Pharmacol. 1996, 140, $1-12$.

(32) Rossi, R.; Giustarini, D.; Milzani, A.; Dalle-Donne, I. Cysteinylation and homocysteinylation of plasma protein thiols during ageing of healthy human beings. J. Cell. Mol. Med. 2009, 13, 31313140 .

(33) Boyer, C.; Bulmus, V.; Liu, J.; Davis, T. P.; Stenzel, M. H.; Barner-Kowollik, C. Well-Defined Protein-Polymer Conjugates via in Situ RAFT Polymerization. J. Am. Chem. Soc. 2007, 129, 7145-7154.

(34) Schwack, W.; Nyanzi, S. Simultaneous UV-Spectrophotometric Determination of $\mathrm{CS}_{2}$ and $\mathrm{COS}$ Using the Piperidine, Pyrrolidine, Ethylenediamine or Morpholine Reagent. Fresenius' J. Anal. Chem. 1993, 345, 705-711. 